\title{
Voluntary Disclosure of GRI and CSR Environmental Criteria in Colombian Companies
}

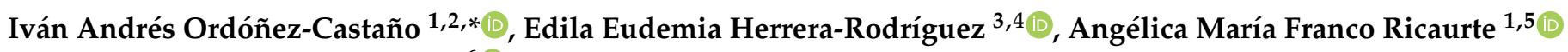 \\ and Luis Enrique Perdomo Mejía ${ }^{6}($ )
}

1 Economic Sciences Faculty, Universidad San Buenaventura Cali (USB), Valle del Cauca 76003, Colombia; amfrancor@usbcali.edu.co or anfrari@doctor.upv.es or angymfr@gmail.com

2 Department of Economy and Social Sciences (DECS), Doctoral School, Universitat Politècnica de València (UPV), 46022 Valencia, Spain

3 Financial Accounting Department, Universidad de Panamá, Panamá 06001, Panama; eherreradeleon@hotmail.com or edilaherrera@gmail.com

4 Miembro del Sistema Nacional de Investigación (SNI) of Secretaría Nacional de Ciencia, Tecnología e Innovación SENACYT-Panamá, Panamá 06001, Panama

5 Faculty of Business Administration and Management, Doctoral School, Universitat Politècnica de València (UPV), 46022 Valencia, Spain

6 Corporación Universitaria Minuto de Dios, Bogotá 76003, Colombia; lperdomo4@uniminuto.edu.co or lepm16@gmail.com

* Correspondence: iaocasta@usbcali.edu.co or ivorcas@doctor.upv.es or ivanorcas@gmail.com

check for updates

Citation: Ordóñez-Castaño, I.A.; Herrera-Rodríguez, E.E.; Franco Ricaurte, A.M.; Perdomo Mejía, L.E. Voluntary Disclosure of GRI and CSR Environmental Criteria in Colombian Companies. Sustainability 2021, 13, 5405. https://doi.org/10.3390/ su13105405

Academic Editors: David Naranjo-Gil and Mark Anthony Camilleri

Received: 16 February 2021

Accepted: 6 April 2021

Published: 12 May 2021

Publisher's Note: MDPI stays neutral with regard to jurisdictional claims in published maps and institutional affiliations.

Copyright: (c) 2021 by the authors. Licensee MDPI, Basel, Switzerland. This article is an open access article distributed under the terms and conditions of the Creative Commons Attribution (CC BY) license (https:/ / creativecommons.org/licenses/by/ $4.0 /)$.
Abstract: The study analysed the asymmetry in the disclosure of environmental criteria of the Global Reporting Initiative (GRI) standard based on financial and non-financial information in 37 companies in 19 sub-sectors of the Colombian economy that were assessed by MERCO (Business Monitor of Corporate Reputation) in 2017 and 2018 in terms of corporate reputation, responsibility, and corporate governance. It is based on the theories of agency, stakeholders, and legitimacy, whereby six hypotheses were postulated. The indicators of environmental criteria were retrieved from the website and sustainability reports of each company, using a dichotomous approach for collecting information on environmental activities. The hypotheses were contrasted with a binary choice and panel data models. The results showed that increasing quality and transparency in voluntarily disclosed information decreases its asymmetry, thereby meeting the information needs of stakeholders, providing confidence, and strengthening corporate social responsibility (CSR) activities. In addition, the most indebted and largest companies disclose less information on environmental activities, in contrast to companies with higher solvency. Overall, the study contributed with the calculation of an asymmetry ratio with the MERCO indicators and the use of the insolvency risk variable as an explanatory variable for disclosure. Additionally, it contributed to the field of study of CSR from the Latin American context.

Keywords: environmental disclosure; GRI standard; corporate reputation; corporate responsibility social; corporate governance; stakeholders

\section{Introduction}

In recent decades, corporate scandals have negatively affected the confidence of interest groups in companies. This lack of confidence has highlighted the need for transparent reporting for two key reasons: Accountability and governance [1]. Thus, corporate governance focuses on the quality, transparency, and reliability of relationships between agents and stakeholders. As such, addressing compliance with corporate governance standards reflects the need for organisations to show more responsibility and transparency to shareholders [2]. Thus, a balanced relationship between companies and society should be maintained [3], because the decisions and actions of entrepreneurs do not only affect themselves, but also their stakeholders, as stated by [4]. Accordingly, the pressure from 
some stakeholder groups (clients, employees, suppliers, owners, and others) to improve the quality and transparency of environmental reporting is increasing [5], such as Global Reporting Initiative (GRI) reporting, which focuses on transparency of information and is still an open topic for discussion as companies are implementing it voluntarily [6].

This research is based on the following three theories: The agency [7], stakeholder [8], and legitimacy [9] theories. These three theories validate the need for transparency in voluntarily disclosing environmental criteria, corporate reputation, responsibility, and corporate governance towards mitigating the problem of information asymmetry between agents and stakeholders [10].

The first, the agency theory, studies the relationship between managers/agents and shareholders/principals [7]. Agents are tasked with maximising the value of the organisation, thus serving the interests of shareholders. The agency theory highlights the advantages of information disclosure in reducing information asymmetry and agency costs. However, this theory predicts the emergence of conflicts of interest, causing agency problems because often agents seek to satisfy their own interests instead of working for the benefit of the company shareholders [7].

The second, the stakeholder theory [8], defines organisation as a group formed by different individuals who may have an interest in the organisation. The main goal of this theory is to balance the contradictory requirements of various stakeholder groups [8] in the implementation of the business strategy within the organisation. One of these demands that has emerged in recent decades is biodiversity conservation, which is being increasingly scrutinised by stakeholders and now represents an important aspect of business ethics [11].

The third, the legitimacy theory, aims at reducing the existing gap between how the public wants the company to behave and how it actually behaves [12]. Companies need to justify that the market requires their services and that they are liked by different social groups [9]. Based on the legitimacy theory, information disclosure seeks to inform the public of changes in company activities and behaviours, justifying their actions to society in order to change the public's perception of any situation that may arise [13]. The legitimacy theory considers the interactions of society as a whole [14] to strengthen trust in stakeholders [15]. Public trust is primarily based on the company behaviour regarding environmental issues. Therefore, the environmental information disclosed by companies can be explained by the legitimacy theory because they respond to changes in social concern for these issues [16].

Thus, environmental information disclosure has become a challenge for business organisations, who need to fulfil the expectations of their stakeholders [17]. Information disclosure is a measure used by most companies to facilitate the understanding of the social and environmental performance of an organisation and to improve relationships with stakeholders $[18,19]$. Transparency and good corporate governance practices may reduce opportunistic behaviours by those who have the most information [20], curtailing conflicts of interest with stakeholders. Therefore, companies are currently highly oriented towards disclosing Global Reporting Initiative's (GRI) environmental criteria in their sustainability reports [18,21-25].

The disclosure of environmental criteria aims at mitigating the problem of information asymmetry between agents and stakeholders. Asymmetric information may occur because one of the parties is better informed than its counterpart about the decisions of the organisation. When investors handle information on earnings different from that known to managers, the problem of information asymmetry may be exacerbated [26-29]. Such situations may drive executives to adopt decisions that benefit their own interests, damaging those of shareholders [10]. This results in information asymmetry that can be reflected in various variables, such as financial variables within companies and common in different sectors of the economy [30-33].

The goal of voluntary disclosure is to improve corporate governance (CG) and corporate social responsibility (CSR) practices. CG emerged with the Sarbanes-Oxley Act and is focused on improving the quality of financial information in the United States in 
response to the amount of accounting frauds in the late 1990s and early 2000s [34]. CG seeks to mitigate the agency problem by restricting the managers' incentives to promote their own interests to the detriment of investors [35] as a mechanism of balancing of power between agents and stakeholders.

CSR refers to a company's management practices for the public good, beyond legal requirements. It is about the business contribution to sustainability. Thus, the disclosure of practices associated with sustainability in companies has evolved due to the information needs of stakeholders [36]. This disclosure in turn has become a key factor for companies that is reflected in their value [37]. Accordingly, proactive CSR companies are better positioned in their sectors [38]. CSR can also be considered the discretionary business practices of companies that are intended to enhance the welfare of society [29,39], including some previously unthinkable aspects such as sustainability, gender parity, environmental awareness, diversity and minorities, and others [40].

As a result of this, companies are increasingly committed to communicating information about their CSR because they believe this approach generates positive results, such as customer loyalty [41]. Organisations frequently participate in CSR so that agents can perceive that the company is operating in a fair market [42], which is a company's ethical commitment to its stakeholders. CSR is therefore an effective strategy broadly conceived as a company's or brand's commitment to maximising long-term economic, social and environmental well-being through business practices, policies, and resources [43].

In this line of thought, the interaction between CSR and sustainability in recent years has been reaffirmed in theory and practice [40,44-49]. However, current empirical studies on corporate engagement in activities that contribute to sustainable development are few, scattered, and poorly reported in Latin American countries. Most of the research is found in countries in other regions, as evidenced from the literature review shown in Table A1 in the Appendix A.

Due to the dynamics in the research field of CSR and sustainability, there are different indices and standards for the disclosure of information such as ESG, EFQM, EMAS, SA 8000, ISO 14000, and the Global Reporting Initiative (GRI) [50]. Additionally, for some Latin American countries, another source of information associated with CSR is MERCO (Monitor Empresarial de Reputación Corporativa-Business Monitor of Corporate Reputation), which is a reputational assessment instrument based on a multi-stakeholder methodology, composed of six assessments and twenty-five sources of information that reports eight indicators in 12 Iberoamerican countries, as open data available on MERCO's website (https: / / www.merco.info/co/ (accessed on 1 March 2021)). These indicators are related to company leadership, corporate responsibility and governance, human talent, consumer dynamics, and digital reputation. This multi-stakeholder methodology is audited by KPMG, in accordance with ISAE 3000 and the International Standard on Quality Control 1 (ISQC1), which publishes its report in MERCO's Process Elaboration Report, which has an annual edition (Informe de Proceso de Elaboración de MERCO) [51].

In this context, this research aimed at analysing the asymmetry and factors in the disclosure of environmental criteria of the GRI-300 standard, based on financial and nonfinancial information in Colombian companies assessed for their corporate reputation, responsibility, and corporate governance by MERCO in 2017 and 2018, as a contribution to research on CSR from Latin America, where this type of study is underdeveloped.

\section{Hypothesis Formulation}

The hypotheses have been formulated based on a literature review of the disclosure of CSR information between 2010 and 2020, that was published in journals included in the ScienceDirect bibliographic database, as outlined in Table A1 in the Appendix A. In this study, the hypotheses are based on the agency, stakeholder, and legitimacy theories, considering factors or characteristics that may affect transparency in the disclosure of information on environmental indicators. These factors are risk of insolvency, size, debt, profitability, and growth. 
The voluntary disclosure of environmental criteria under the GRI standard increases transparency and improves activities associated with CSR, reducing the problem of information asymmetry. In this regard, researchers have examined the various benefits of participating in CSR using direct financial measures of corporate financial performance (CFP) and have found that CSR benefits companies by enhancing analyst follow-up [52]. Moreover, it increases corporate benefits, improves communication with shareholders on financial matters [53], fosters a more effective corporate governance, increases company value [54-56], and reduces equity costs [57-59] by improving the credit rating [60] and increasing the forecast accuracy of analysts.

The agency theory [7] highlights that increasing transparency in the disclosure of environmental criteria reduces the problem of information asymmetry, in addition to serving the interests of stakeholders, according to the stakeholder theory [8]. The legitimacy theory [9] also supports information disclosure on environmental criteria, thus explaining company actions. Thus, the following hypothesis is formulated:

H1. The voluntary disclosure of environmental criteria under the GRI standard increases transparency and improves activities associated with CSR, reducing the information asymmetry problem.

Previous studies on the relationship between risk and information asymmetry argue that managers of high-risk companies can make more effort to correct information asymmetry. According to [61,62], reputation building is important for companies under intense monitoring and with high risks. Such companies must provide additional high-quality information. Similarly, $[63,64]$ postulate that companies whose risk is difficult to define and measure may be reluctant to issue debt to avoid adverse selection by their stakeholders.

According to the agency theory [7], companies with increased solvency may tend to reveal more information associated with CSR, thus reducing the problem of information asymmetry. Conversely, the stakeholder theory [8] could be motivating information disclosure on company solvency, thus justifying any decision made by the company. The legitimacy theory [9] also supports the disclosure of information on CSR towards reducing the information asymmetry between how the public perceives the behaviour of the company and how the latter actually behaves. The following hypothesis is formulated:

H2. Companies with a lower risk of insolvency disclose more environmental activities associated with CSR, reducing the asymmetry of information with their stakeholders.

Large organisations perform more activities related to environmental criteria. In addition, they have more complex organisational structures than small companies [65]. Accordingly, the agency theory [7] states that these companies disclose more information to reduce the information asymmetry problem and agency costs. As large companies have more stakeholders than small companies, the stakeholder theory [8] aims at disclosing more information. Information disclosure, supported by the legitimacy theory, also reduces the gap between the amount of information disclosed by large companies and that of small companies [9]. Thus, the following hypothesis is formulated:

H3. Large firms disclose more information about their engagement in environmental activities associated with CSR, reducing information asymmetry with their stakeholders.

Company debt may indicate that an organisation is expecting investments to grow and increase its profits [20]. According to the agency theory [7], the most indebted companies may be disclosing more information on environmental activities associated with CSR, thus justifying the use of their resources. The stakeholder theory [8] also justifies the disclosure of environmental activities to clarify the actions of a company to its stakeholders. The legitimacy theory [9] supports information disclosure to justify a company's borrowing decisions to the public. The following hypothesis is formulated:

H4. Companies with greater debt disclose more information on environmental activities associated with CSR, reducing the information asymmetry with their stakeholders. 
According to the agency theory [7], the most profitable companies tend to disclose more information to show their financial situation to stakeholders. By disclosing information on profitability levels, the company would be meeting the performance demands of different stakeholders, according to the precepts of the stakeholder theory [8], whilst creating a public perception of its financial stability, in accordance with the assumptions of the legitimacy theory [9]. Thus, the following hypothesis is formulated:

H5. Companies with higher profitability disclose more information regarding their environmental activities associated with CSR, reducing the information asymmetry with their stakeholders.

According to the principles of the agency theory [7], as companies grow, they should disclose more information to the stakeholders to reduce the information asymmetry problem and agency costs. The stakeholder theory [8] also justifies information disclosure by meeting the requirements of stakeholders in terms of expansion into other markets. The legitimacy theory [9] considers information disclosure on company growth as a way to show the efficiency of the company and thus reduce the information gap. The following hypothesis is formulated:

H6. Companies with higher growth disclose more environmental activities associated with CSR, reducing the information asymmetry with their stakeholders.

\section{Methodology}

This study analyses the asymmetry and factors in voluntary disclosure of environmental criteria of Colombian companies reporting under the GRI-300 standard. Colombia began its homogenisation and standardisation of this standard in 2017. In order to do this, 37 companies belonging to 19 subsectors of the Colombian economy were observed that report under the GRI standard, and that have also been assessed for corporate reputation, responsibility, and governance by MERCO in 2017 and 2018. The decision to use data from these two years for this research was made because the financial information audited by the Colombian government's control bodies is only available up to 2018. Moreover, non-financial information from the same two periods was used.

Thus, two dependent variables were defined in the research. The first variable was disclosure of environmental criteria of the GRI-300 standard (materials, energy, water, biodiversity, emissions, effluents, waste, compliance, and environmental assessment of suppliers). A matrix with a dichotomous approach was constructed with the information on these criteria, where companies that disclosed more than $90 \%$ of the criteria were assigned one, and those that disclosed less were assigned zero.

The second dependent variable was constructed from information from the MERCO responsabilidad y gobierno corporativo (MERCO Corporate responsibility and governance) and MERCO reputación corporativa (MERCO corporate responsibility) data series by 2017 and 2018. The first series evaluates the economic and financial aspects, the quality of the supply, human talent, ethics, corporate responsibility, internationalisation, and innovation of each company; an indicator was generated for each company [51], which could be interpreted as the effort made by the organisation to show its capabilities $(\sigma)$. The second series evaluates the ethical behaviour, transparency, good governance, responsibility to employees, commitment to the environment, climate change, and contribution to the community; an indicator was generated for each company [51], and these aspects show the stakeholders the actions taken by the company associated with CSR $(\eta)$. In this sense, what company managers disclose to the market is compared with what stakeholders perceive from this information disclosure, so that as this gap decreases, the problem of information asymmetry can be reduced. This is in line with the principles of the agency, stakeholder, and legitimacy theories.

Considering these two indicators, an asymmetry ratio (IS) was calculated, which according to Equation (1) compares the relationship between the internal aspects of the 
company $(\sigma)$ with the stakeholders' perception of it $(\eta)$. In this way, a company will have more symmetric information if the result of the equation tends to one.

$$
I S=\sigma \div \eta
$$

Table 1 shows the dependent variables explained above and the independent variables defined from the literature review presented in Table A1. The dependent variables were disclosure of environmental aspects of the GRI standard and information asymmetry. The independent variables were size, debt, profitability, growth, and insolvency risk. In addition to a dichotomous variable that was constructed with the information disclosed by each company on its website and sustainability reports on environmental activities not covered by the GRI standard, this variable was constructed from a dichotomous approach matrix.

Table 1. Definition of dependent and independent variables.

\begin{tabular}{|c|c|c|}
\hline Variable & Definition & $\begin{array}{c}\text { Acronym of the } \\
\text { Variable }\end{array}$ \\
\hline \multicolumn{3}{|c|}{ Dependent variables } \\
\hline $\begin{array}{l}\text { Disclosure of information on } \\
\text { environmental aspects (Discl) }\end{array}$ & $\begin{array}{l}\text { Aspects reported by companies under } \\
\text { the GRI- } 300 \text { standard. }\end{array}$ & d_gri \\
\hline $\begin{array}{l}\text { Information asymmetry } \\
\text { (D_IS) }\end{array}$ & $\begin{array}{l}\text { Calculation of the asymmetry ratio (IS) } \\
\text { from the relationship between the } \\
\text { corporate reputation indicator }(\sigma) \text { and } \\
\text { corporate responsibility and } \\
\text { governance }(\eta) \text {. }\end{array}$ & D_IS \\
\hline \multicolumn{3}{|c|}{ Variable explanations } \\
\hline Size & Natural logarithm of total assets. & assets \\
\hline Debt & Ratio of total liabilities to total equity. & debt \\
\hline Profit & Ratio of net profit to sales. & profit \\
\hline Grow & Operating income percentage change. & C_sales \\
\hline Risk & Z-score according to the Altman model. & z_cat \\
\hline $\begin{array}{l}\text { Environmental practices not } \\
\text { covered by the GRI standard } \\
\text { (act_r_ma) }\end{array}$ & $\begin{array}{l}\text { Environmental actions of the observed } \\
\text { companies that were disclosed on their } \\
\text { websites or sustainability reports but } \\
\text { did not follow the GRI standard. }\end{array}$ & act_r_ma \\
\hline
\end{tabular}

Source: The authors.

\section{Models for Hypothesis Validation}

To test hypothesis one, a binary choice model was used as shown in Equation (2). From the explanatory variables, we determine the probability ( $p i)$ [64] that disclosure of information on environmental aspects (d_gri) increases or decreases depending on information asymmetry (D_IS), environmental activities not covered by the GRI standard (act_r_ma), size (assets), profitability (profit), growth (c_sales), debt (debt).

$$
p_{i} \equiv \operatorname{Pr}\left[y_{i}=1 \mid x\right]=F\left(x^{\prime}{ }_{i} \beta\right)
$$

To test the other hypotheses, a panel data model with two study periods (2017 and 2018) was used to analyse the data by ordinary least squares (OLS) regression. To check the consistency and efficiency of the regression coefficients, the Breush-Pegan test [66] was used and for multicollinearity the variance inflation test (VIF) was used. The model aimed at explaining the behaviour of the information asymmetry (D_IS) based on size, profitability, growth, debt, and the risk of insolvency, according to Equation (3), in addition to the environmental activities variable not covered by the GRI standard (act_r_amb) as a proxy variable of CRS actions.

$D_{-} g r i_{t}=\beta_{1 t}+\beta_{2 t}$ Size $+\beta_{3 t}$ Profit $+\beta_{4 t}$ Growth $+\beta_{5 t}$ Debt $+\beta_{5 t}$ Risk $+\beta_{5 t}$ Act_r_amb $+\mu$ 


\section{Results}

The results of this study show that the companies analysed between 2017 and 2018 showed an increase in the dependent variable Information Asymmetry (IS) from 48.15 to $51.85 \%$. Regarding the Disclosure of Environmental Aspects of the GRI standard (d_gri), the Colombian companies showed the highest interest in disclosing compliance with environmental regulations, followed by emissions, water, and energy consumption. The sectors with the least information asymmetry were construction and infrastructure, pharmaceuticals, and passenger transport, whereas the most asymmetric sectors are those of public services and Family Welfare Fund.

Table 2 outlines the descriptive statistics of the independent variables. The companies taken in this study are medium and large in terms of their level of assets, according to the business classification in Colombia. Indebtedness ranges from $34.13 \%$ to $72.37 \%$. The average profitability is $23.01 \%$, which indicates that most of the companies are in good financial health. Growth has averaged $4.61 \%$ above the economic growth rate in Colombia for the period under analysis. Finally, these companies do not present a high risk of insolvency in the future.

Table 2. Descriptive statistics of the explanatory variables of the models.

\begin{tabular}{lccc}
\hline \multicolumn{1}{c}{ Variable } & $\begin{array}{c}\text { Acronym of } \\
\text { the Variable }\end{array}$ & Mean $(\boldsymbol{\mu})$ & Standard Deviation $(\delta)$ \\
\hline Size & assets & 8.2594 & 1.9867 \\
Profitability & profit & 0.2301 & 0.4542 \\
Growth & C_sales & 4.6062 & 1.1977 \\
Debt & debt & 0.5325 & 0.1912 \\
Risk of insolvency & z_cat & 2.8965 & 0.8819 \\
\hline
\end{tabular}

Source: The authors.

Hypothesis Testing

The results of the marginal effects of the binary choice model, which are outlined in Table 3, indicated that, among the higher the asymmetry of information, the probability of disclosure environmental aspects under the GRI standard decreases by $21.39 \%$. In addition, large companies have a low probability of disclosure of these aspects; otherwise, depending on their profitability, this probability is $70.32 \%$. The same results were found in studies conducted by $[67,68]$. Companies that disclose environmental activities on their websites or reports and their disclosure of environmental aspects under the GRI standard showed a positive, although not statistically significant, relationship. Growth and indebtedness have a negative relationship with environmental disclosure, which is consistent with the literature, but the results were not statistically significant in this research.

Table 3. Results from the binary choice model.

\begin{tabular}{|c|c|c|c|c|c|}
\hline \multicolumn{2}{|c|}{$\mathrm{Y}=$ Disclosure of Information on Environmental Aspects (d_gri) } & \multirow{2}{*}{\multicolumn{2}{|c|}{ Coefficients $(\beta)$}} & \multirow{2}{*}{\multicolumn{2}{|c|}{ Marginal Effects (dy/dx) }} \\
\hline \multicolumn{2}{|l|}{ Explanatory Variables } & & & & \\
\hline Information asymmetry & D_IS & -1.2408 & * & -0.2139 & * \\
\hline Environmental practices not covered by the GRI standard & act_r_ma & 16.509 & & 2.5456 & \\
\hline Size & asset & $\begin{array}{c}-4.88 \times \\
10^{-8}\end{array}$ & ** & $\begin{array}{c}-7.53 \times \\
10^{-9}\end{array}$ & $* *$ \\
\hline Profitability & r_op & -4.5607 & $* *$ & -0.7032 & $* *$ \\
\hline Growth & C_sales & -0.015 & & -0.0023 & \\
\hline Debt & debt & -2.4761 & & -0.3818 & \\
\hline Constant & _cons & 2.3123 & $* *$ & & \\
\hline \multicolumn{6}{|c|}{${ }^{*} p<0.1 ;{ }^{* *} p<0.05$} \\
\hline
\end{tabular}


These results confirm the first hypothesis $\left(\mathrm{H}_{1}\right)$ on the voluntary disclosure of environmental criteria under the GRI standard, increasing transparency, improving activities associated with CSR, and reducing the problem of information asymmetry. These results validate the assumptions of the agency [7], stakeholder [8], and legitimacy [9] theories.

The dependent variables used in the OLS panel data model were tested for heteroscedasticity and multicollinearity, in both cases the defined variables are accepted, so that the coefficients are consistent to test the hypotheses. Table 4 shows the regression results to test hypotheses two to five.

Table 4. Results from the panel data model.

\begin{tabular}{|c|c|c|c|}
\hline \multicolumn{2}{|c|}{ Y = Information Asymmetry (D_IS) } & \multirow{2}{*}{\multicolumn{2}{|c|}{ Coefficients $(\beta)$}} \\
\hline \multicolumn{2}{|l|}{ Explanatory Variables } & & \\
\hline Size & assets & $6.53 \times 10^{9}$ & * \\
\hline Profitability & r_net & 0.0571 & \\
\hline Growth & C_sales & $1.62 \times 10^{-2}$ & \\
\hline Debt & debt & -0.4273 & ** \\
\hline $\begin{array}{l}\text { Risk } \\
\text { Environmental } \\
\text { practices not covered } \\
\text { by the GRI standard }\end{array}$ & $\begin{array}{l}\text { z_cat } \\
\text { act_r_ma }\end{array}$ & $\begin{array}{l}0.0715 \\
0.2365\end{array}$ & $* *$ \\
\hline Constant & _cons & 0.2183 & ** \\
\hline \multicolumn{4}{|c|}{${ }^{*} p<0.1 ; * * p<0.05$} \\
\hline
\end{tabular}

Source: The authors.

Thus, as companies minimise their risk of insolvency, the information symmetry increases to $7.15 \%$, thereby mitigating the information asymmetry problem. Therefore, the hypothesis according to which companies with a lower risk of insolvency $\left(\mathrm{H}_{2}\right)$ conduct more environmental activities associated with CSR, reducing the information asymmetry with their stakeholders, is confirmed. Accordingly, the studies by [58,69-71] found a positive relationship between risk measured through Tobin's $Q$ variable and the disclosure of environmental information. These results confirm the assumptions of the agency [7], stakeholder [8], and legitimacy [9] theories.

The results regarding hypothesis $\left(\mathrm{H}_{3}\right)$ on size, presented in Table 4 , show that companies with a $1 \%$ increase in size increase symmetrical information disclosing more information on environmental activities associated with CSR at 90\% significance level. These findings indicate that as companies increase in size, they consider that they will be more robust and it will be better to disclose this type of information to their stakeholders. These results corroborate the findings of [58,72-77], and accept the assumptions of the agency [7], stakeholder [8], and legitimacy [9] theories.

According to the results outlined in Table 4, companies with higher debt tend to disclose less information about their environmental aspects, which increases information asymmetry. Thus, the fourth hypothesis $\left(\mathrm{H}_{4}\right)$ is rejected. These results are in line with the study by [73] and reject the assumptions of the agency [7], stakeholder [8], and legitimacy [9] theories.

However, the last two hypotheses, (H5) and (H6), on profitability and growth, respectively, were not confirmed in this study because the model coefficients were not significantly different, as presented in Table 4. Nevertheless, the positive relationship between the profitability and symmetrical information aspects by the companies corroborates the findings of $[69,78]$. In turn, the results on growth were also non-significant, maintaining a negative relationship with the dependent variable, similar to the studies by $[68,76,79]$. 


\section{Conclusions}

This study analysed the asymmetry and factors in the disclosure of environmental criteria of the Global Reporting Initiative (GRI) standard based on financial and non-financial information in Colombian companies rated in corporate reputation, responsibility, and corporate governance by MERCO in 2017 and 2018. It was found that as the disclosure of environmental indicators increases, the asymmetry of information decreases, thus showing good corporate governance practices, transparency, and trust towards stakeholders. Increasing the quality and transparency of information lowers agency costs, thus meeting the information needs of stakeholders, providing confidence, and improving CSR activities. Therefore, the agency, stakeholder, and legitimacy theories are confirmed.

The results on financial performance show that more profitable companies tend to reduce the asymmetry problem by reporting under the GRI standard. As companies increase in size, they report fewer activities under the GRI standard. With regard to information asymmetry, when companies are able to increase their size and decrease their debt and insolvency risk, they achieve reductions in their information asymmetry and in turn tend to disclose more of their environmental activities through their website or sustainability reports, but not necessarily under the GRI standard.

More indebted companies disclose less information and conduct fewer environmental activities associated with CSR, increasing the information asymmetry with their stakeholders. Companies with higher levels of debt do not consider it necessary to explain to stakeholders that they may be incurring debt to increase their investments. Conversely, companies with lower solvency risk are motivated to disclose more information on environmental aspects, increasing transparency regarding their CSR activities.

As companies increase in size, they report fewer activities under the GRI standard. Regarding information asymmetry, companies that can increase their size and reduce their debt and insolvency risk achieve reductions in their information asymmetry and in turn tend to disclose more of their environmental activities through their website or sustainability reports, but not necessarily under the GRI standard. Accordingly, these results accept the proposed agency, stakeholder, and legitimacy theories. Thus, the largest companies consider that they have sufficient reputation and need not incur costs to collect and disseminate such information.

Research on CRS, information disclosure, and the problem of information asymmetry that achieve an empirical verification based on the financial and non-financial conditions of companies have been developed mostly in European, Asian, and North American contexts. However, in Latin America they are few and have only been addressed in Argentina, Mexico, and Brazil, so research on these issues in other countries in the region is significant, as in the case of this research, which focused on the Colombian context, identifying similar aspects with the business characteristics of other countries according to the literature.

This study is a contribution to the field of research as it uses the insolvency risk variable as an explanatory variable for information asymmetry, and therefore its impact on the disclosure of information on environmental indicators. In addition, the disclosure of environmental criteria was analysed under the GRI standard and other sources of disclosure of these criteria of companies that were measured in corporate reputation, responsibility, and corporate governance with audited indicators, such as MERCO and the inclusion of the insolvency risk variable.

Future research along the methodological lines of this study can be carried out using other indicators that measure corporate reputation, corporate governance, and CSR criteria such as ESG. Other standards such as EFQM, EMAS, SA 8000, ISO 14000, among others, can also be considered. Another alternative for future research is to carry out comparative studies between different Latin American countries on their CSR actions, especially environmental or social. 
Author Contributions: All authors were involved in conceptualization, methodology, validation, formal analysis, research, writing-original draft preparation, writing-review and editing. Software I.A.O.-C. Data curation I.A.O.-C. and L.E.P.M. Visualization I.A.O.-C. and A.M.F.R., project administration and funding acquisition I.A.O.-C. and E.E.H.-R. All authors have read and agreed to the published version of the manuscript.

Funding: The project had the logistical and financial support of the University of San Buenaventura at Cali (Universidad de San Buenaventura Cali-USBCALI), within the framework of the research project entitled "Pasivos intangibles y sostenibilidad corporativa: investigación comparada entre Panamá, Colombia y Argentina" (Intangible liabilities and corporate sustainability: Comparative research between Panama, Colombia, and Argentina), ID 34216055, within the framework of the permanent call for external projects endorsed by the USBCALI Research Directorate (Dirección de Investigaciones BonaventurianoDIB). In addition; this research was made possible thanks to the support of the Sistema Nacional de Investigación (SNI) of Secretaría Nacional de Ciencia, Tecnología e Innovación (Panamá), and by the Universidad de Panamá by mean of the Vicerrectoría de Investigación y Postgrado, with the call for research funds.

Institutional Review Board Statement: Not applicable

Informed Consent Statement: Not applicable

Data Availability Statement: Not applicable

Conflicts of Interest: The authors declare that there are no conflicts of interests.

\section{Appendix A}


Table A1. Empirical literature supporting hypothesis formulation.

\begin{tabular}{|c|c|c|c|c|c|c|}
\hline Analysis Group & Variable & Reference & Country & Industry & Model & Relationship \\
\hline \multirow{15}{*}{$\begin{array}{l}\text { Activities associated } \\
\text { with CSR }\end{array}$} & \multirow[b]{2}{*}{$\begin{array}{c}\text { Disclosure of } \\
\text { environmental aspects }\end{array}$} & [67] & United States & Multiple & Panel & + \\
\hline & & [68] & $\begin{array}{l}\text { Spain, Brazil, USA, Italy, Australia, } \\
\text { France, Russia, Germany, Chile, and } \\
\text { Mexico, among others. }\end{array}$ & $\begin{array}{l}\text { Energy, Mining, Oil, Finance } \\
\text { and Construction }\end{array}$ & Panel & + \\
\hline & \multirow{13}{*}{ Voluntary disclosure } & [76] & China & Multiple & Panel & SR \\
\hline & & {$[74]$} & $\begin{array}{c}\text { France, Germany, Italy, Spain, } \\
\text { Switzerland, Sweden, and the United } \\
\text { Kingdom }\end{array}$ & 19 sectors & Panel & SR \\
\hline & & [80] & Bangladesh & Banks & Panel & - \\
\hline & & [81] & Belgium & 11 sectors & Panel & + \\
\hline & & [69] & $\begin{array}{l}\text { Austria, Belgium, Denmark, Finland, } \\
\text { France, Germany, Greece, Ireland, Italy, } \\
\text { The Netherlands, Norway, Portugal, } \\
\text { Spain, Sweden, and the United Kingdom. }\end{array}$ & 8 sectors & Panel & + \\
\hline & & [82] & China & $\begin{array}{l}\text { Manufacturing } \\
\text { (publicly traded) }\end{array}$ & Panel & + \\
\hline & & [77] & China & Multiple & Panel & + \\
\hline & & [58] & 31 countries & Multiple & Panel & SR \\
\hline & & [75] & The United States & $\begin{array}{l}\text { Four chemical industries, } \\
\text { machinery and equipment, } \\
\text { electronics and } \\
\text { business services }\end{array}$ & Panel & + \\
\hline & & [83] & Spain & Multiple & Panel & SR \\
\hline & & [73] & France & $\begin{array}{l}\text { Multiple-(Société des } \\
\text { Bourses Françaises-SBF, } \\
\text { French stock market) }\end{array}$ & Panel & + \\
\hline & & {$[84]$} & South Africa & Multiple-SBF & Panel & SR \\
\hline & & [71] & New York Stock Exchange (NYSE) & Multiple & Panel & + \\
\hline
\end{tabular}


Table A1. Cont.

\begin{tabular}{|c|c|c|c|c|c|c|}
\hline Analysis Group & Variable & Reference & Country & Industry & Model & Relationship \\
\hline \multirow{8}{*}{ Risk } & \multirow{8}{*}{ Q-Tobin } & [74] & $\begin{array}{l}\text { France, Germany, Italy, Spain, } \\
\text { Switzerland, Sweden, and the } \\
\text { United Kingdom }\end{array}$ & 19 Sectors & Panel & - \\
\hline & & [85] & Taiwan & 31 Sectors & Panel & \\
\hline & & [82] & China & $\begin{array}{l}\text { Manufacturing } \\
\text { (publicly traded) }\end{array}$ & Panel & - \\
\hline & & [77] & China & Multiple & Panel & - \\
\hline & & [58] & 31 countries & Multiple & Panel & + \\
\hline & & [73] & France & Multiple-SBF & Panel & - \\
\hline & & {$[70]$} & $\begin{array}{c}\text { Egypt, Jordan, Kuwait, Morocco, Oman, } \\
\text { Saudi Arabia, Tunisia, Turkey, and the } \\
\text { United Arab Emirates }\end{array}$ & Multiple, non-financial & Panel & + \\
\hline & & {$[71]$} & NYSE & Multiple & Panel & + \\
\hline \multirow{6}{*}{ Size } & $\begin{array}{l}\text { Total number } \\
\text { of employees }\end{array}$ & [74] & $\begin{array}{c}\text { France, Germany, Italy, Spain, } \\
\text { Switzerland, Sweden, and the United } \\
\text { Kingdom }\end{array}$ & 19 Sectors & Panel & - \\
\hline & $\begin{array}{l}\text { Natural logarithm } \\
\text { of employees }\end{array}$ & [85] & Taiwan & 31 Sectors & Panel & \\
\hline & \multirow{4}{*}{$\begin{array}{l}\text { Natural logarithm } \\
\text { of assets }\end{array}$} & {$[76]$} & China & Multiple & Panel & - \\
\hline & & [86] & London & Multiple & Panel & + \\
\hline & & [69] & $\begin{array}{l}\text { Austria, Belgium, Denmark, Finland, } \\
\text { France, Germany, Greece, Ireland, Italy, } \\
\text { The Netherlands, Norway, Portugal, } \\
\text { Spain, Sweden, and the United Kingdom. }\end{array}$ & 8 Sectors & Panel & + \\
\hline & & [77] & China & Multiple & Panel & - \\
\hline
\end{tabular}


Table A1. Cont.

\begin{tabular}{|c|c|c|c|c|c|c|}
\hline Analysis Group & Variable & Reference & Country & Industry & Model & Relationship \\
\hline & & [58] & 31 countries & Multiple & Panel & - \\
\hline & & [75] & The United States & $\begin{array}{l}\text { Four chemical industries, } \\
\text { machinery and equipment, } \\
\text { electronics and business } \\
\text { services }\end{array}$ & Panel & - \\
\hline & & {$[83]$} & Spain & Multiple & Panel & + \\
\hline & & [73] & France & Multiple-SBF & Panel & - \\
\hline & & [71] & The United States & $\begin{array}{l}\text { Pulp and paper, chemicals, } \\
\text { oil and gas, metals and } \\
\text { mining, and utilities }\end{array}$ & Panel & - \\
\hline & $\begin{array}{l}\text { Natural logarithm of } \\
\text { assets }\end{array}$ & [71] & NYSE & Multiple & Panel & + \\
\hline & Record of total assets & [79] & Argentina & $\begin{array}{l}\text { Multiple (Agriculture, } \\
\text { Construction, Finance and } \\
\text { Insurance, Manufacturing, } \\
\text { Mining, Real Estate, Retail, } \\
\text { Services, Transportation, } \\
\text { and Gas/Electric Services) }\end{array}$ & Panel & + \\
\hline & $\begin{array}{l}\text { Natural logarithm of } \\
\text { corporate income }\end{array}$ & [70] & $\begin{array}{c}\text { Egypt, Jordan, Kuwait, Morocco, Oman, } \\
\text { Saudi Arabia, Tunisia, Turkey and the } \\
\text { United Arab Emirates }\end{array}$ & Multiple, non-financial & Panel & + \\
\hline \multirow{4}{*}{ Debt } & \multirow{4}{*}{ Leverage } & {$[74]$} & $\begin{array}{l}\text { France, Germany, Italy, Spain, } \\
\text { Switzerland, Sweden, and the } \\
\text { United Kingdom }\end{array}$ & 19 Sectors & Panel & + \\
\hline & & [76] & China & Multiple & Panel & + \\
\hline & & [68] & $\begin{array}{l}\text { Spain, Brazil, USA, Italy, Australia, } \\
\text { France, Russia, Germany, Chile, and } \\
\text { Mexico, among others. }\end{array}$ & $\begin{array}{l}\text { Energy, Mining, Oil, Finance } \\
\text { and Construction }\end{array}$ & Panel & + \\
\hline & & [86] & London & Multiple & Panel & + \\
\hline
\end{tabular}


Table A1. Cont.

\begin{tabular}{|c|c|c|c|c|c|c|}
\hline Analysis Group & Variable & Reference & Country & Industry & Model & Relationship \\
\hline & & [69] & $\begin{array}{l}\text { Austria, Belgium, Denmark, Finland, } \\
\text { France, Germany, Greece, Ireland, Italy, } \\
\text { The Netherlands, Norway, Portugal, } \\
\text { Spain, Sweden, and the United Kingdom. }\end{array}$ & 8 Sectors & Panel & + \\
\hline & & [82] & China & $\begin{array}{l}\text { Manufacturing (publicly } \\
\text { traded) }\end{array}$ & Panel & + \\
\hline & & [58] & 31 countries & Multiple & Panel & + \\
\hline & & [73] & France & Multiple-SBF & Panel & - \\
\hline & & {$[83]$} & Spain & Multiple & Panel & + \\
\hline & & [84] & South Africa & Multiple-SBF & Panel & + \\
\hline & & {$[70]$} & $\begin{array}{c}\text { Egypt, Jordan, Kuwait, Morocco, Oman, } \\
\text { Saudi Arabia, Tunisia, Turkey, and the } \\
\text { United Arab Emirates }\end{array}$ & Multiple non-financial & Panel & + \\
\hline & & & & Multiple Sectors & & \\
\hline & & [79] & Argentina & $\begin{array}{l}\text { Agriculture, Construction, } \\
\text { Finance and Insurance, } \\
\text { Manufacturing, Mining, } \\
\text { Real Estate, Retail, Services, } \\
\text { Transportation, and } \\
\text { Gas/Electric Services. }\end{array}$ & Panel & + \\
\hline & & [71] & NYSE & Multiple & Panel & + \\
\hline \multirow[b]{2}{*}{ Profitability } & \multirow[b]{2}{*}{ Asset profitability } & [76] & China & Multiple & Panel & - \\
\hline & & {$[68]$} & $\begin{array}{l}\text { Spain, Brazil, USA, Italy, Australia, } \\
\text { France, Russia, Germany, Chile, and } \\
\text { Mexico, among others. }\end{array}$ & $\begin{array}{l}\text { Energy, Mining, Oil, Finance } \\
\text { and Construction }\end{array}$ & Panel & - \\
\hline
\end{tabular}


Table A1. Cont.

\begin{tabular}{|c|c|c|c|c|c|c|}
\hline Analysis Group & Variable & Reference & Country & Industry & Model & Relationship \\
\hline & & {$[86]$} & London & Multiple & Panel & + \\
\hline & & [69] & $\begin{array}{l}\text { Austria, Belgium, Denmark, Finland, } \\
\text { France, Germany, Greece, Ireland, Italy, } \\
\text { The Netherlands, Norway, Portugal, } \\
\text { Spain, Sweden, and the United Kingdom. }\end{array}$ & 8 Sectors & Panel & + \\
\hline & & [85] & Taiwan & 31 Sectors & Panel & + \\
\hline & & {$[84]$} & South Africa & Multiple-SBF & Panel & - \\
\hline & & {$[86]$} & The United Kingdom & Multiple & Panel & - \\
\hline & & [78] & Argentina & $\begin{array}{c}\text { Multiple (Agriculture, } \\
\text { Construction, Finance and } \\
\text { Insurance, Manufacturing, } \\
\text { Mining, Real Estate, Retail, } \\
\text { Services, Transportation and } \\
\text { Gas/Electric Services) }\end{array}$ & Panel & + \\
\hline & Net profitability & [71] & NYSE & Multiple & Panel & - \\
\hline \multirow{4}{*}{ Growth } & \multirow[b]{2}{*}{$\begin{array}{l}\text { Variation in the level of } \\
\text { sales }\end{array}$} & [76] & China & Multiple & & - \\
\hline & & [68] & $\begin{array}{c}\text { Spain, Brazil, USA, Italy, Australia, } \\
\text { France, Russia, Germany, Chile, and } \\
\text { Mexico, among others. }\end{array}$ & $\begin{array}{l}\text { Energy, Mining, Oil, Finance } \\
\text { and Construction }\end{array}$ & Panel & - \\
\hline & & \multirow[b]{2}{*}{ [79] } & & Multiple & \multirow[b]{2}{*}{ Panel } & \multirow[b]{2}{*}{-} \\
\hline & $\begin{array}{l}\text { Market value divided by } \\
\text { book value }\end{array}$ & & Argentina & $\begin{array}{l}\text { Agriculture, Construction, } \\
\text { Finance and Insurance, } \\
\text { Manufacturing, Mining, } \\
\text { Real Estate, Retail, Services, } \\
\text { Transportation, and } \\
\text { Gas/Electric Services. }\end{array}$ & & \\
\hline
\end{tabular}




\section{References}

1. Stefănescu, C.A.; Oprişor, T.; Sintejudeanu, M.A. An original assessment tool for transparency in the public sector based on the integrated reporting approach. J. Account. Manag. Inf. Syst. 2016, 15, 542-564.

2. Adiloglu, B.; Vuran, B. The relationship between the financial ratios and transparency levels of financial information disclosures within the scope of corporate governance: Evidence from Turkey. J. Appl. Bus. Res. 2012, 28, 543-554. [CrossRef]

3. Janang, J.S.; Joseph, C.; Said, R. Corporate Governance and Corporate Social Responsibility Society Disclosure: The Application of Legitimacy Theory. Int. J. Bus. Soc. 2020, 21, 660-678.

4. Bowen, H.R. Social Responsibilities of the Businessman; Harper: London, UK, 1953; Available online: https://books.google.com.co/ books?id=ALIPAwAAQBAJ\&printsec=frontcover\&hl=es\&source=gbs_ge_summary_r\&cad=0\#v=onepage\&q\&f=false (accessed on 1 March 2021).

5. Fernandez-Feijoo, B.; Romero, S.; Ruiz, S. Effect of Stakeholders' Pressure on Transparency of Sustainability Reports within the GRI Framework. J. Bus. Ethics 2014, 122, 53-63. [CrossRef]

6. Machado, B.A.A.; Dias, L.C.P.; Fonseca, A. Transparency of materiality analysis in GRI-based sustainability reports. Corp. Soc. Responsib. Environ. Manag. 2021, 28, 570-580. [CrossRef]

7. Jensen, M.C.; Meckling, W.H. Theory of the firm: Managerial behavior, agency costs and ownership structure. J. Financ. Econ. 1976, 3, 305-360. [CrossRef]

8. Freeman, R.E. The stakeholder approach revisited. Z. Wirtsch. Unternehm. 2004, 5, 228-241. [CrossRef]

9. Shocker, A.D.; Sethi, S.P. An approach to incorporating societal preferences in developing corporate action strategies. Calif. Manag. Rev. 1973, 15, 97-105. [CrossRef]

10. Akerlof, G.A. The market for "lemons": Quality uncertainty and the market mechanism. Q. J. Econ. 1970, 84, 488-500. [CrossRef]

11. Boiral, O.; Heras-Saizarbitoria, I. Managing biodiversity through stakeholder involvement: Why, who, and for what initiatives? J. Bus. Ethics 2017, 140, 403-421. [CrossRef]

12. Gray, R.; Kouhy, R.; Lavers, S. Corporate social and environmental reporting A review of the literature and a longitudinal study of UK disclosure. Account. Audit. Account. J. 1995, 8, 47-77. [CrossRef]

13. Lindblom, C.E. Success through inattention in school administration and elsewhere. Educ. Adm. Q. 1994, 30, 199-213. [CrossRef]

14. Chan, M.C.; Watson, J.; Woodliff, D. Corporate governance quality and CSR disclosures. J. Bus. Ethics 2014, 125, 59-73. [CrossRef]

15. Dowling, J.; Pfeffer, J. Organizational legitimacy: Social values and organizational behavior. Pac. Sociol. Rev. 1975, 18, 122-136. [CrossRef]

16. Husillos, J.F. An approach to the environmental disclosures of the listed Spanish firms from the legitimacy theory. Span. J. Financ. Account./Rev. Española Financ. Contab. 2007, 36, 97-121. [CrossRef]

17. Al Farooque, O; Ahulu, H. Environmental reporting in the UK, Australia, and South African multinational companies. J. Dev. Areas 2015, 49, 103-118. [CrossRef]

18. Fuente, J.; García-Sánchez, I.; Lozano, M. The role of the board of directors in the adoption of GRI guidelines for the disclosure of CSR information. J. Clean. Prod. 2017, 141, 737-750. [CrossRef]

19. Galli, D.; Bassanini, F. Reporting sustainability in China: Evidence from the global powers of luxury goods. Sustainability 2020, 12, 3940. [CrossRef]

20. Herrera Rodríguez, E.E.; Macagnan, C.B. Bancos en Brasil y España: Factores Explicativos de Revelación del Capital Relacional. Banks in Brazil and Spain: Explanatory factors for the disclosure of relational capital. Cuad. Contab. 2015, 16, 40.

21. Bellucci, M.; Simoni, L.; Acuti, D.; Manetti, G. Stakeholder engagement and dialogic accounting: Empirical evidence in sustainability reporting. Account. Audit. Account. J. 2019, 32, 1467-1499. [CrossRef]

22. Correa, R.; Ribeiro, H.; Souza, M.T.S. Disclosure Ambiental: Informações sobre GEES das Empresas Brasileiras que Declaram no Nivel A+ da GRI. Rev. Adm. Unimep 2014, 12, 1-22. [CrossRef]

23. De Mascena, K.M.C.; Fischmann, A.A.; Boaventura, J.M.G. Stakeholder prioritization in Brazilian companies disclosing GRI reports. Braz. Bus. Rev. 2018, 15, 17-32. [CrossRef]

24. Di Domenico, D.; Tormem, L.; Mazzioni, S. Nível de disclosure nos relatórios de sustentabilidade em conformidade com o Global Reporting Initiative (GRI). Level of disclosure in sustainability reports in compliance with Global Reporting Initiative (GRI). Rev. Catarin. Ciência Contábil 2017, 16, 49. [CrossRef]

25. Kolk, A. The social responsibility of international business: From ethics and the environment to CSR and sustainable development. J. World Bus. 2016, 51, 23-34. [CrossRef]

26. Bhattacharya, N.; Desai, H.; Venkataraman, K. Does earnings quality affect information asymmetry? Evidence from trading costs*. Contemp. Account. Res. 2012, 30, 482-516. [CrossRef]

27. Diamond, D.W.; Verrecchia, R.E. Disclosure, liquidity, and the cost of capital. J. Financ. 1991, 46, 1325-1359. [CrossRef]

28. Kim, O.; Verrecchia, R.E. Market liquidity and volume around earnings announcements. J. Account. Econ. 1994, $17,41-67$. [CrossRef]

29. Korschun, D.; Bhattacharya, C.; Swain, S.D. Corporate social responsibility, customer orientation, and the job performance of frontline employees. J. Mark. 2014, 78, 20-37. [CrossRef]

30. Chang, C.; Yu, X. Informational Efficiency and Liquidity Premium as the Determinants of Capital Structure. J. Financ. Quant. Anal. 2010, 45, 401-440. Available online: http:/ / www.jstor.org/stable/27801490 (accessed on 1 March 2021). [CrossRef] 
31. Mac an Bhaird, C.; Lucey, B. Determinants of capital structure in Irish SMEs. Small Bus. Econ. 2010, 35, 357-375. [CrossRef]

32. Bharath, S.T.; Pasquariello, P.; Wu, G. Does Asymmetric Information Drive Capital Structure Decisions? Rev. Financ. Stud. 2008, 22, 3211-3243. [CrossRef]

33. Morri, G.; Beretta, C. The capital structure determinants of REITs. Is it a peculiar industry? J. Eur. Real Estate Res. 2008, 1, 6-57. [CrossRef]

34. Bhagat, S.; Bolton, B. Director ownership, governance, and performance. J. Financ. Quant. Anal. 2013, 48, 105-135. [CrossRef]

35. Shleifer, A.; Vishny, R.W. A survey of corporate governance. J. Financ. 1997, 52, 737-783. [CrossRef]

36. Camilleri, M.A. Theoretical insights on integrated reporting: The inclusion of non-financial capitals in corporate disclosures. Corp. Commun. Int. J. 2018, 23, 567-581. [CrossRef]

37. Spallini, S.; Milone, V.; Nisio, A.; Romanazzi, P. The dimension of sustainability: A comparative analysis of broadness of information in italian companies. Sustainability 2021, 13, 1457. [CrossRef]

38. Mathis, A. Corporate social responsibility and policy making: What role does communication play? Bus. Strat. Environ. 2007, 16, 366-385. [CrossRef]

39. Mishra, S.; Modi, S.B. Corporate social responsibility and shareholder wealth: The role of marketing capability. J. Mark. 2016, 80, 26-46. [CrossRef]

40. Martín, P.A.; Valls, M.C.; Cruz, S. Corporate Social Responsibility: A Bibliometric Research. In Encyclopedia of Business and Professional Ethics; Poff, D.C., Michalos, A.C., Eds.; Springer: Cham, Switzerland, 2021.

41. Habel, J.; Schons, L.M.; Alavi, S.; Wieseke, J. Warm glow or extra charge? The ambivalent effect of corporate social responsibility activities on customers' perceived price fairness. J. Mark. 2016, 80, 84-105. [CrossRef]

42. Campbell, J.L. Why would corporations behave in socially responsible ways? An institutional theory of corporate social responsibility. In Academy of Management Review; Academy of Management: Briarcliff Manor, NY, USA, 2007; Volume 32, pp. 946-967. [CrossRef]

43. Du, S.; Bhattacharya, C.B.; Sen, S. Corporate Social Responsibility and competitive advantage: Overcoming the trust barrier. Manag. Sci. 2011, 57, 1528-1545. [CrossRef]

44. Ceptureanu, S.I.; Ceptureanu, E.G.; Luchian, C.E.; Luchian, I. Community based programs sustainability. A multidimensional analysis of sustainability factors. Sustainability 2018, 10, 870. [CrossRef]

45. Zhao, H.; Zhang, F.; Kwon, J. Corporate social responsibility research in international business journals: An author co-citation analysis. Int. Bus. Rev. 2018, 27, 389-400. [CrossRef]

46. Low, M.P.; Siegel, D. A bibliometric analysis of employee-centred corporate social responsibility research in the 2000s. Soc. Responsib. J. 2019, 16, 691-717. [CrossRef]

47. Ye, N.; Kueh, T.-B.; Hou, L.; Liu, Y.; Yu, H. A bibliometric analysis of corporate social responsibility in sustainable development. J. Clean. Prod. 2020, 272, 122679. [CrossRef]

48. Hu, Q.; Zhu, T.; Lin, C.L.; Chen, T.; Chin, T. Corporate Social Responsibility and Firm Performance in China's Manufacturing: A Global Perspective of Business Models. Sustainability 2021, 13, 2388. [CrossRef]

49. Afzali, H.; Kim, S.S. Consumers' Responses to Corporate Social Responsibility: The Mediating Role of CSR Authenticity. Sustainability 2021, 13, 2224. [CrossRef]

50. Escrig-Olmedo, E.; Jesus Muñoz-Torres, M.; Fernandez-Izquierdo, M.A.; Jesús Muñoz-Torres, M.; Ángeles Fernández-Izquierdo, M. Socially responsible investing: Sustainability indices, ESG rating and information provider agencies SUSTAINABILITY Special Issue "Microfinance and Sustainable Development" View project Socially responsible investing: Sustainability indices, ESG rating and information provider agencies. Int. J. Sustain. Econ. 2010, 2, 4. [CrossRef]

51. MERCO: Ranking Empresas Colombia 2018. Available online: https://www.merco.info/files/2018/10/660/metodologia-einforme-de-verificacion-merco-empresas-co-2018.pdf (accessed on 1 November 2019).

52. Hong, H.; Kacperczyk, M. The price of sin: The effects of social norms on markets. J. Financ. Econ. 2009, 93, 15-36. [CrossRef]

53. Cheng, B.; Ioannou, I.; Serafeim, G. Corporate social responsibility and access to finance. Strat. Manag. J. 2014, 35, 1-23. [CrossRef]

54. Blazovich, J.L.; Smith, L.M. Ethical corporate citizenship: Does it pay? In Research on Professional Responsibility and Ethics in Accounting; Jeffrey, C., Ed.; Emerald Group Publishing Limited: Bingley, UK, 2011; Volume 15, pp. 127-163. [CrossRef]

55. Jo, H.; Harjoto, M.A. Corporate governance and firm value: The impact of corporate social responsibility. J. Bus. Ethics 2011, 103, 351-383. [CrossRef]

56. Jo, H.; Harjoto, M.A. The causal effect of corporate governance on corporate social responsibility. J. Bus. Ethics 2012, 106, 53-72. [CrossRef]

57. Dhaliwal, D.S.; Li, O.Z.; Tsang, A.; Yang, Y.G. Voluntary nonfinancial disclosure and the cost of equity capital: The initiation of corporate social responsibility reporting. Account. Rev. 2011, 86, 59-100. [CrossRef]

58. Dhaliwal, D.S.; Radhakrishnan, S.; Tsang, A.; Yang, Y.G. Nonfinancial disclosure and analyst forecast accuracy: International evidence on corporate social responsibility disclosure. Account. Rev. 2012, 87, 723-759. [CrossRef]

59. El Ghoul, S.; Guedhami, O.; Kwok, C.C.; Mishra, D.R. Does corporate social responsibility affect the cost of capital? J. Bank. Financ. 2011, 35, 2388-2406. [CrossRef]

60. Attig, N.; El Ghoul, S.; Guedhami, O.; Suh, J. Corporate social responsibility and credit ratings. J. Bus. Ethics 2013, 117, 679-694. [CrossRef] 
61. Diamond, D.W. Monitoring and reputation: The choice between bank loans and directly placed debt. J. Political Econ. 1991, 99, 689-721. [CrossRef]

62. Sufi, A. Information asymmetry and financing arrangements: Evidence from syndicated loans. J. Financ. 2007, 62, 629-668. [CrossRef]

63. Halov, N.; Heider, F. Capital structure, risk and asymmetric information. Q. J. Financ. 2011, 1, 767-809. [CrossRef]

64. Herrera Rodríguez, E.E.; Ordóñez-Castaño, I.A. Disclosure of intangible liabilities: Comparative study of the banking sectors in Panama and Colombia. J. Appl. Account. Res. 2020, 21, 635-656. [CrossRef]

65. Singhvi, S.S.; Desai, H.B. An empirical analysis of the quality of corporate financial disclosure. Account. Rev. 1971, 46, 129-138. [CrossRef]

66. Breusch, T.S.; Pagan, A.R. A simple test for heteroscedasticity and random coefficient variation. Econom. J. Econom. Soc. 1979, 47, 1287. [CrossRef]

67. Rupley, K.H.; Brown, D.; Marshall, R.S. Governance, media and the quality of environmental disclosure. J. Account. Public Policy 2012, 31, 610-640. [CrossRef]

68. Barkemeyer, R.; Preuss, L.; Lee, L. On the effectiveness of private transnational governance regimes-Evaluating corporate sustainability reporting according to the Global Reporting Initiative. J. World Bus. 2015, 50, 312-325. [CrossRef]

69. Eliwa, Y.; Aboud, A.; Saleh, A. ESG practices and the cost of debt: Evidence from EU countries. Crit. Perspect. Account. 2019, 102097. [CrossRef]

70. Moumen, N.; Ben Othman, H.; Hussainey, K. The value relevance of risk disclosure in annual reports: Evidence from MENA emerging markets. Res. Int. Bus. Financ. 2015, 34, 177-204. [CrossRef]

71. Bui, B.; Houqe, M.N.; Zaman, M. Climate governance effects on carbon disclosure and performance. Br. Account. Rev. 2020, 52, 100880. [CrossRef]

72. Clarkson, P.M.; Fang, X.; Li, Y.; Richardson, G. The relevance of environmental disclosures: Are such disclosures incrementally informative? J. Account. Public Policy 2013, 32, 410-431. [CrossRef]

73. de La Bruslerie, H.; Gabteni, H. Voluntary disclosure of financial information by French firms: Does the introduction of IFRS matter? Adv. Account. 2014, 30, 367-380. [CrossRef]

74. Hummel, K.; Schlick, C. The relationship between sustainability performance and sustainability disclosure-Reconciling voluntary disclosure theory and legitimacy theory. J. Account. Public Policy 2016, 35, 455-476. [CrossRef]

75. Rezaee, Z.; Tuo, L. Voluntary disclosure of non-financial information and its association with sustainability performance. Adv. Account. 2017, 39, 47-59. [CrossRef]

76. Cai, W.; Lee, E.; Xu, A.L.; Zeng, C. Does corporate social responsibility disclosure reduce the information disadvantage of foreign investors? J. Int. Account. Audit. Tax. 2019, 34, 12-29. [CrossRef]

77. Shan, Y.G. Do corporate governance and disclosure tone drive voluntary disclosure of related-party transactions in China? J. Int. Account. Audit. Tax. 2019, 34, 30-48. [CrossRef]

78. Debenedetti, A.; Philippe, D.; Chaney, D.; Humphreys, A. Maintaining legitimacy in contested mature markets through discursive strategies: The case of corporate environmentalism in the French automotive industry. Ind. Mark. Manag. 2021, 92, 332-343. [CrossRef]

79. Alali, F.; Romero, S. The use of the Internet for corporate reporting in the Mercosur (Southern common market): The Argentina case. Adv. Account. 2012, 28, 157-167. [CrossRef]

80. Khan, H.Z.; Bose, S.; Johns, R. Regulatory influences on CSR practices within banks in an emerging economy: Do banks merely comply? Crit. Perspect. Account. 2020, 71, 102096. [CrossRef]

81. Bouten, L.; Everaert, P.; Van Liedekerke, L.; De Moor, L.; Christiaens, J. Corporate social responsibility reporting: A comprehensive picture? Account Forum 2011, 35, 187-204. [CrossRef]

82. Lee, E.; Walker, M.; Zeng, C. Do Chinese state subsidies affect voluntary corporate social responsibility disclosure? J. Account. Public Policy 2017, 36, 179-200. [CrossRef]

83. Gisbert, A.; Navallas, B. The association between voluntary disclosure and corporate governance in the presence of severe agency conflicts. Adv. Account. 2013, 29, 286-298. [CrossRef]

84. Bernardi, C.; Stark, A.W. Environmental, social and governance disclosure, integrated reporting, and the accuracy of analyst forecasts. Br. Account. Rev. 2018, 50, 16-31. [CrossRef]

85. Chen, Y.-L.; Cheng, H.-Y. Public family businesses and corporate social responsibility assurance: The role of mimetic pressures. J. Account. Public Policy 2020, 39, 106734. [CrossRef]

86. Tauringana, V.; Chithambo, L. The effect of DEFRA guidance on greenhouse gas disclosure. Br. Account. Rev. 2015, 47, 425-444. [CrossRef] 